\title{
The role of counselor in preventing students' attitudes toward cheating
}

\author{
Meilinda $^{1}$, Mudjiran' ${ }^{2}$, Sufyarma Marsidin ${ }^{3}$ \\ ${ }^{123}$ Universitas Negeri Padang, Padang -Indonesia, ( meilindanasution7731@gmail.com)
}

\begin{abstract}
Attitude toward cheating is formed based on someone's perspective, belief, and knowledge or information received about cheating. If the students' attitude toward cheating ispositive, their affective evaluation tends to accept and assume that cheating is normal. The positive attitudes are more likely to be an action of approaching, liking even expecting cheating behavior to occur. Conversely, if the students' attitude is negative, their affective evaluation tends to reject, disagree, and assume that cheating is a prohibited act and leadstheir attitude to become negative behavior. Therefore, counselors need to provide the understanding of guidance and counseling service as one of alternatives in preventing students' cheating. This paper discusses the concept of cheating and the role of counselor to help students avoid cheating.
\end{abstract}

Keywords: attitides toward cheating, counselor, student.

This is an open access article distributed under the Creative Commons 4.0 Attribution License, the which permits unrestricted use, distribution, and reproduction in any medium, Provided the original work is properly cited. @ 2018 by author and Faculty of education, UniversitasNegeri Padang.

\section{Introduction}

Education is a conscious, planned, programmed, and continuous effort to help students develop their potential optimally on the cognitive, affective, and psychomotor aspects. Education serves to develop the potential of students to become intelligent and qualified people. Shaping honest charactersis expected from the goal of education but in reality it has not been implemented maximally because there are still some students who do academic dishonesty like cheating. Cheating is a common activity encountered in the learning process. Unfortunately, this problem is not taken seriously by education practitioners so that cheating is still happening nowadays.

Cheating is often called as academic dishonesty. Cheating currently does not only happen in Elementary school, Junior High school, and Senior High school, even in Higher Education or university. At this stage of development, students need to have a negative attitude toward cheating. Students who have negative attitudes toward cheating are more likely to stay away from, avoid, hate, and refuse cheating. Otherwise, students who have positive attitude are more likely to approach, favor, and even expect it to occur.

The main problem now is still many students who have positive attitudes toward cheating. Based on the observation conducted at MAN Panyabungan, cheating was considered as a normal activity because students caught cheating were not seriously got consequences from teachers. These perspectives shape the students' positive attitudes toward cheating. Therefore, the students need to cultivate negative attitudes toward cheating in order to stay away from, to hate, and to avoid 
cheating. This case is certainly a particular concern for many parties including counselors as professionals through guidance and counseling service at schools. The counselors need to provide the concept of the attitude toward cheating.

\section{Discussion}

\section{Basic Concepts of Attitudes toward Cheating}

Attitude is a person's tendency to behave. Students will cheat when they agree and believe that cheating is positive act and believe that others want them to do it. So that, what they believe has an effect on their behavior. Walgito (2011) proposes three components of attitude. The first component is cognitive aspect (perceptual component) related to knowledge, perspective, belief such as things related to how people perceive the object of attitude. The second is affective component related to pleasure or displeasure with attitude objects. The last is behavioural component associated with a person's tendency to behave toward attitude objects. Before cheating, students first are given understanding of those three aspects against cheating. Students who think and believe that cheating is a behavior that will not harm yourself and others or feel that other friends also like it, then students will tend to cheat.

Regarding the definition of attitude, many experts put forward according to their point of view. According to Walgito (2011), attitude is an organization of opinion, a person's belief about objects or situations that are accompanied with certain feelings and provide a basis for the person to behave. Moreover, Chaplin (2011) states that attitudes are a relatively stable and continuous predisposition or tendency to behave or react in a certain way to other individuals, objects, institutions, or problems. In addition, Ali and Asrori (2008) also state that attitude is one of the very important psychological aspects of the individual because the attitude is a tendency to behave so that it will vary a lot of one's behaviors.

According to Romney and Steinbart (in Barzegar \& Khezri, 2012: 1), cheating is defined as"To use any means to achieve an unfair and unjust privileges that include: lying, concealing the truth, deceive, deceit and violation of trust". It means gaining something unfairly including lying, covering the truth, deceit, and breach of trust. Indarto and Masrun (2004) define cheating as dishonest and illegal activity in getting answers at the time of the test. Cheating is one of the most frequent and ofteneducational phenomena in the teaching and learning process, but ironically it rarely gets serious attention from education practitioners in Indonesia (Musslifah, 2012). In addition, Clariana, Gotzens, Badia, and Cladellas (2012) declare cheating as a tendency to use someone's works or ideas.

From the aforementioned definitions, it can be understood that the attitude toward cheating is a readiness to act in particular on cheating.If the students' judgment is good at cheating then they will tend to agree withit. On the contrary, when cheating is considered bad by the students then they tends to disagree with it.

Cheating is influenced by several factors. Brown and Choong (2011) suggest that there are several factors related to cheating, namely the desire to get a high score, campus culture, difficulties encountered, no time to learn, the perception of subject matter and lack of quality teachers. Furthermore, Strom and Strom (2007) state there are five factors that influence cheating. They are the pressure to get a high score, lack of time to complete the task, other students also cheating, thought lesson material not important, etc. In addition, gender factors also have an effect on cheating. Mujahidah (2009) affirms that male acts dishonestly more dominant than female does. It happens because male students have low self-control, shame, and high level of courage.

The cheating phenomenon that is synonymous with deception does not improve the quality of the students in any way. Therefore, cheating is not in accordance with educational goals, it can even be a threat to the enforcement and achievement of actual educational goals. According to Sari, Marjohan, 
and Neviyarni (2013), cheating students do during the exam can erode a positive personality of students. Likewise, Chapman and Davis (in Barzegar \& Khezri, 2012) explain that ,based on research literature, it is very important to overcome cheating because in most cases people who ever have cheated will carry out such bad behavior into their work environment.

Abramovits and Bouville (in Mujahidah, 2009) also express that the cheating behavior fixed continuously will become part of the individual it self. Consequently, the community becomes permissive toward cheating behavior. This situation will result in cheating behavior being part of the culture that affects the loss of moral values in every aspect of life and social order and even can weaken the power of society. It is in accordance with the statement from Koentjaraningrat (2011) who says that if human finds an action that proved efficient in tackling a problem of life, then the behavior will certainly be repeated if the same problem is re-experienced.

Based on the survey of Litbang Media Group (in Musslifah, 2012) conducted on April 19, 2007, in six major cities in Indonesia (Makassar, Surabaya, Yogyakarta, Bandung, Jakarta and Medan),almost $70 \%$ of respondents said that they had cheated when they were still in school and college. In addition, Hartanto (2012) conducted a study in one of the private schools in Yogyakarta known that the most dominant practices of cheatingare copying, seeing, or asking for someone's answers.

Cheating ultimately becomes international concern. The survey of Josephson Institute of Ethics in America (in Strom \& Strom, 2007) with respondents 36.000 junior high school students found that $60 \%$ of students accepted and admitted to cheating during exams and doing works. Cheating does not only happen to junior and senior high school students, but also in college. For example, the findings from The Epoch Time (in Strom \& Strom, 2007) which took the data from 900 students, there are $83 \%$ of which admitted to cheating when conducting tests or exams. Furthermore,Callahan confirms that cheating is also found in students in Australia, England, India, Japan, Korea, Spain, and Scotland (in Strom \& Strom, 2007).

Cheating has become a parasite that is slowly eroding the character of students. It also is very likely to happen if it does not get good handling. Hartanto (2012) states that it really happens to students and it can be observed from the the news in the mass media revealed thatcheating is done during the execution of the national final exam or school final examination. Marjohan, Asri, Gusraredi.,Ifdil., and Afriani (2012) also assert that the presence of people in educational units involved and brighten such a bad behavior. The answer from the exam questions that are not yet clear is sold to the candidates of the national exam students at a fairly high price.

\section{The Role of Counselor}

The abovementioned concepts emphasize that the preventing efforts from counselor still needed through utilizing various types of guidance and counseling services to develop the character and potential of the students.American School Counselor Association (ASCA) shows the support by stating that professional school counselors need to take an active role in initiating, facilitating, and promoting character education programs in the school curriculum. The professional school counselor, as a part of the school community and as ahighly resourceful person, takes an active role by working cooperatively withthe teachers and administration in providing character education in theschools as an integral part of the school curriculum and activities. It is understandable that the counselor should be able to become a facilitator at school by working with other school personnel so that the function of guidance and counseling runs smoothly.

Guidance and counseling service is conducted in various development areas, services and support activities. It refers to seven areas of development, ten types of counseling and guidance services and six forms of support activities. The ten types of guidance and counseling service are: (1) Orientation Services, which helps people understand a new environment to adapt and to facilitate when theyare 
in such an environment; (2) Information Services, which helps people receive and understand various knowledge related to personal, social, learning, career /occupation, and further education fields; (3) Placement and Distribution Services, which helps people obtain the right placement and distribution in various jobs/activities in accordance with their potential; (4) Content Mastery Services, which helps people to master certain content, especially useful competencies and habits in family and community life; (5) Individual Counseling Services, which assist people in alleviating their personal problems; (6) Group Guidance Services, which facilitatepeople in personal development, social skills, learning activities, career/occupation, decision-making, and performing certain activities through group dynamics; (7) Group Counseling Services, which enables people to discuss and eradicatetheir personal problems through group dynamics; (8) Consultation, which permits people and/or other parties in gaining insight, understanding, and single ways needed in handling their conditions and/or problems; (9) Mediation, which helps students solve their problems and improve relationships among them when conflict occurs and (10) Advocacy Services, which aidspeople to meet their rights violated by other people/organizations in their fulfillment (Prayitno, 2014).

Counselors are educators who are considered as professionals with the main task of implementing the learning process in the field of counseling services (Prayitno, 2014). Like other professional educators, the counselor also has some requirements, which are the standard of academic qualification and competence of counselor (Permendiknas number 27, 2008). In providing counseling services, counselors are expected to provide counseling services for the realization of someone's optimally independent development. By achieving thevision and missionin guidance and counseling service, the students in passing their development tasks definitely have positive impactsofit.

Regarding the problems described above, the students have to be given the understanding of acheating concept, and its effects on their behavior in order for the students have a negative attitude toward cheating. Negative attitude toward cheating isperspective, feeling, and tendency to not cheat or refuse to cheat. The preventiongiven should be able to minimize the factors that influence the occurrence of cheating so that an effective life and independent performance can be achieved because the students anyway must develop their potential through education.

Based on the types of service previously mentioned, the services that can be provided by counselors to prevent students' cheating behavior are: (1) Information services, which is intended to help students obtain the necessary information as a reference for attitude and action. It also serves as a direction of self-development to avoid cheating. The counselor as the service provider must fully master the information that becomes the content of the service, get to know both the students and their needs, and use creative ways to carry out the service, and ultimately through this service the counselor succeeds in preventing the students from cheating. The information given is the understanding of attitudes toward cheating behavior, discipline in learning, confidence, the development of information and technology, prevention of cheating, and other concepts related to cheating, (2) Group Guidance Services, which aims to train students' ability to socialize, especially the ability of good communication in expressing their feelings, perceptions, thoughts, and insights. Counselors can take advantage of group dynamics to discuss specific topics and issues related to cheating behavior. With group dynamics, students can share information to others so that students are knowledgeable and insightful with more focused, flexible and broad, and dynamic. Through this service, it is expected to train students to appreciate other people's feelings and rights in their group and to express themselves honestly and in the right way, and (3) Content Mastery Services, with mastery of content students are expected to have insight, understanding, directing judgment and attitude as well as mastering certain ways or habits to meet their needs and to overcome their problems (Prayitno, 2014). 


\section{Conclusion}

The pervious discussion reviews the importance of preventing students' attitude toward cheating. Attitude is a tendency to behave. The students' positive attitudes toward cheating aremore likely to like, approach, even expect such a behavior. Conversely, the students' negative attitudes are more likely to disagree and reject cheating. Through theefforts of prevention given, the students are expected to have a negative attitude towards cheating so that they can refuse, stay away and avoid cheating. Counselors as educators who have an important role to help students avoid cheating can carry out various types of service by utilizing the guidance and counseling service so that students stay away from cheating. Counseling and guidance services provided will be more successful when there is assistance from several parties such as parents, teachers, and principals in order to prevent students' cheating behavior.

\section{References}

Ali, M., \& Asrori, M. (2008). Psikologi Remaja Perkembangan Peserta Didik. Jakarta: Bumi Aksara. Afdal, A. (2015). Kolaboratif Kerja Konselor Masa Depan. Jurnal Konseling dan Pendidikan, 3(2).

Barzegar, K., \& Khezri, H. (2012). Predicting Academic Cheating Among the Fifth Grade Students; The Role of Self Efficacy and Academic Self-Handicapping. Journal of Life Science and Biomedicine, 2(1): 1-6.

Brown, B. S., \& Choong, P. (2011). Identifying the Salient Dimensions of Student Cheating and Their Key Determinants in a Private University. Journal of Business \& Economics Research (JBER), 1(3): 75-84.

Chaplin, J. P. (2011). Kamus Lengkap Psikologi. Terjemahan oleh Kartono, K. Jakarta: Raja Grafindo Persada.

Clariana, M., Gotzens, C., Badia, D. M., \& Cladellas, R. (2012). Procrastination and Cheating from Secondary School to University. Electronic Journal of Research in Educational Psychology, 10(27). 737-754

Hartanto, D. (2012). Bimbingan \& Konseling Menyontek: Mengungkap Akar Masalah dan Solusinya. Jakarta: Indeks.

Indarto, Y., \& Masrun. (2004). Hubungan Antara Orientasi Penguasaan dan Orientasi Performasi dengan Intensi Menyontek. Sosiosains, 17(3): 411-421.

Koentjaraningrat. (2011). Pengantar Antropologi. Jakarta: Rineka Cipta.

Marjohan., Asri, Z., Gusraredi., Ifdil., \& Afriani, N. (2012). Biografi Keilmuan Prayitno dalam Ranah Konseling dan Pendidikan. Padang: UNP Press.

Mujahidah. (2009). Perilaku Menyontek Laki-laki dan Perempuan: Studi meta analisis. Jurnal Psikologi, II(2): 177-199.

Prayitno. (2014). Seri Layanan dan Kegiatan Pendukung Konseling. Padang: PPK FIP UNP.

Sari, I., Marjohan., \& Neviyarni. (2013). Locus of Control dan Perilaku Menyontek serta Implikasinya Terhadap Bimbingan dan Konseling (Studi pada Siswa Sekolah Menengah Atas Padang Ganting). Jurnal Ilmiah Konseling, 2(1): 267-272.

Strom, P. S., \& Strom, R. D. (2007). Cheating in Middle School and High School. Journal the Educational Forum. 71: 104-116.

Walgito, B. (2011). Teori-teori Psikologi Sosial. Yogyakarta: Andi Offset. 